\title{
Metastatic zosteriform cutaneous squamous cell carcinoma
}

\author{
Gabriel Crevier-Sorbo MD MSc, Aura Cernii MD, Andrei Cepoi MD
}

Cite as: CMAJ 2021 October 4;193:E1536. doi: 10.1503/cmaj.210551

A 59-year-old man presented to the emergency department with a 1-month history of an excruciatingly painful, erythematous rash with papules, crusted ulcerations and axillary lymphadenopathy. The rash extended from his right axilla to the midline along the T3 and T4 dermatomes (Figure 1). He had been treated with an extended course of oral acyclovir and cephalexin for presumed superinfected herpes zoster without improvement. His medical history was unremarkable except for having his right ring finger amputated 6 months earlier because of a cutaneous squamous cell carcinoma that had invaded the distal phalanx. He was immunocompetent and had undergone a negative whole-body positron emission tomography-computed tomography scan 1 month before the appearance of the rash.

We performed a biopsy of a skin lesion, and pathological analysis showed a poorly differentiated squamous cell carcinoma with perineural invasion and infiltration into the subdermal tissue. We diagnosed metastatic, zosteriform, cutaneous squamous cell carcinoma and referred the patient for palliative chemotherapy and radiotherapy. He died 1 month later from rapid progression of his cancer.

Cutaneous squamous cell carcinomas are usually treated by surgical excision, and fewer than $4 \%$ metastasize. ${ }^{1}$ Risk factors for metastatic disease include male sex, low socioeconomic status, immunosuppressed state and age older than 80 years. ${ }^{1}$ Tumour diameter larger than $2.0 \mathrm{~cm}$, invasion beyond the subcutaneous fat, perineuronal invasion, bone erosion, desmoplastic subtype and poor tumour differentiation are associated with lymphatic spread and distal metastasis. ${ }^{2}$

Herpes zoster or shingles often presents as an exquisitely tender dermatomal rash with grouped vesicles on an erythematous base, and can last 3-4 weeks. A zosteriform pattern of metastatic cutaneous squamous cell carcinoma can closely resemble shingles and is also exquisitely tender. It is uncommon, and likely occurs through retrograde lymphangitic spread of tumour cells; it carries a dismal prognosis. ${ }^{3-6}$ The diagnosis requires a high index of suspicion in patients with a history of skin cancer, or other cancers, who present with a zoster-like rash refractory to antiviral therapy. ${ }^{4,5}$

\section{References}

1. Venables ZC, Autier P, Nijsten T, et al. Nationwide incidence of metastatic cutaneous squamous cell carcinoma in England. JAMA Dermatol 2019;155:298-306.

2. Que SKT, Zwald FO, Schmults CD. Cutaneous squamous cell carcinoma: incidence, risk factors, diagnosis, and staging. J Am Acad Dermatol 2018;78:237-47.

3. Savoia P, Fava P, Deboli T, et al. Zosteriform cutaneous metastases: a literature meta-analysis and a clinical report of three melanoma cases. Dermatol Surg 2009;35:1355-63.

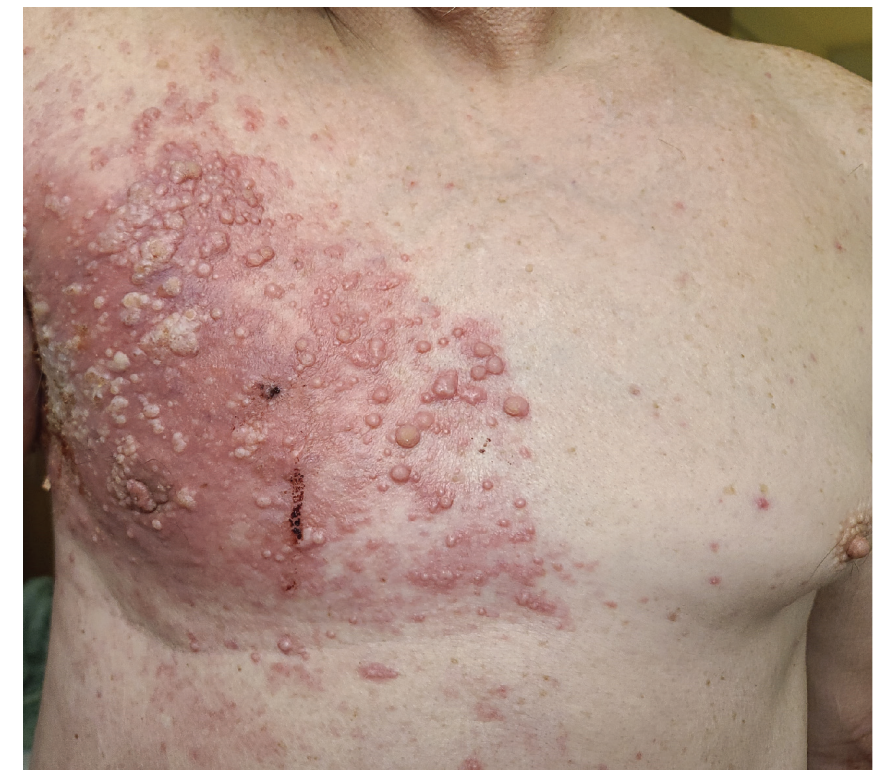

Figure 1: Photograph of a 59-year-old man with metastatic cutaneous squamous cell carcinoma, showing an erythematous rash with papules and ulcerations with a right $\mathrm{T} 3$ and $\mathrm{T} 4$ dermatomal distribution.

4. Maki Y, Kimizuka Y, Murakami K, et al. Zosteriform skin metastasis caused by retrograde lymphatic migration of metastatic squamous cell lung carcinoma. BMC Pulm Med 2021;21:41.

5. Kikuchi Y, Matsuyama A, Nomura K. Zosteriform metastatic skin cancer: report of three cases and review of the literature. Dermatology 2001;202:336-8.

6. Williams DC, Livingston R. High aggressive herpetiform squamous cell carcinoma. Plast Reconstr Surg Glob Open 2015;3:e522.

\section{Competing interests: None declared.}

This article has been peer reviewed.

The authors have obtained patient consent.

Affiliation: Department of Family Medicine, University of Vermont Champlain Valley Physicians Hospital, Plattsburgh, NY

Content licence: This is an Open Access article distributed in accordance with the terms of the Creative Commons Attribution (CC BY-NC-ND 4.0) licence, which permits use, distribution and reproduction in any medium, provided that the original publication is properly cited, the use is noncommercial (i.e., research or educational use), and no modifications or adaptations are made. See: https://creativecommons.org/ licenses/by-nc-nd/4.0/

Correspondence to: Gabriel Crevier-Sorbo, gcrevier-sorbo@cvph.org 